THURSDAY, SEPTEMBER I0, 1874

\section{THE INTERNATIONAL CONGRESS OF ORIENTALISTS}

THE International Congress of Orientalists, which is 1 about to be held in London, from the I4th to the Igth of September, promises fairly to become one of the most striking events of the autumn. This philological pariiament is the successor and outcome of a similar Congress held last year in Paris, which inaugurated a movement likely to bear good fruit for a long time to come. The idea of holding once during every year a meeting of this nature in a different city originated with M. Gabriel Mortillet, a distinguished French savant, who proposed an annual International Congress of Prehistoric Archæology. Of these, the first was held at Neuchâtel, in Switzerland, in 1866. At the Brussels Congress of this body, two monarchs, the Kings of Denmark and Sweden, commissioned agents to represent them on the occasion, and their example was followed by the municipal authorities of Bologna. The French Congress of Orientalists of 1873 was mainly due to the exertions of M. Léon de Rosny, who organised its machinery with the co-operation of MM. Madier de Montjau and Zelinsky. The most prominent considerations of this Congress were directed towards the Japanese Empire, history, and language, and a very large and extrernely interesting mass of literary and scientific material was accumulated, and is now in course of publication and distribution among the members of that meeting. This collection of essays is all the more important when we consider how few really accurate channels of knowledge concerning that remote country are available to the European student. Although the French Congress was supported by a greater number of members than the approaching London Congress seems at present likely to enrol, nevertheless it was not well attended; for the principal Orientalists who occupy fauteuils in the Institute held aloof from various motives, while on the other hand the savants of Germany, in consequence of the recent war, were, however willing, yet prevented by the French national feeling from making their appearance in the capital city. Yet by far the larger number of the most eminent professors in Germany enrolled their names on the list of the supporters of the Congress.

The London Congress has, however, "no difficulties of this nature to surmount, and it will without doubt show a great preponderance of learned Germans ; at the same time a reference to the list of members indicates a very strong contingent from the other side of the Channel. The vital principle of these Congresses is, that each, at the conclusion of its labours, transmits its powers to a chosen individual who becomes president for the ensuing year; this president is elected after the country has been fixed upon in which the next meeting is to be held. The Paris Congress, in accordance with this principle, selected London, as the metropolis of England, to be the place where the Congress of the current year should be held; and this was done out of respect for the learning of the country, although very flattering and advantageous offers had been made by other European countries, which would have VoL $\mathrm{x} .-$ No. 254 perhaps accorded an official reception more cordial than is likely to be given by the imperial authorities in this country. At the conclusion of the French Congress in September last year, Dr. Samuel Birch, K.R., Keeper of the Egyptian and Oriental Antiquities in the British Museum, a gentleman whose knowledge of the whole range of ancient remains, whether Greek, Roman, or Oriental, makes him facile princeps in this particular study, was elected president of the English meeting, and an executive committee was afterwards nominated to carry out the necessary arrangements. These preliminary matters are now so far advanced that the programme has just been issued, and the sittings, which will occupy the entire week, will commence on Monday next, the I4th inst. These Congresses are likely to produce several very excellent effects, by bringing together distinguished Orientalists who would probably not otherwise become personally acquainted with each other; by the mutual interchange of ideas, by the bringing about some understanding on many disputed points, and by the arrangement of some uniform system of transliteration and transcription of Oriental texts. But above all it will call public attention to; the importance of Oriental studies, alas! too long neglected in Great Britain, and will elevate in public opinion the position of Oriental students and studies, which already exercise, and will hereafter still more powerfully exercise, an influence over European thought.

The number of English members is at present about 180 , daily increasing and comprising all the names distinguished in Oriental studies; indeed, it would be difficult to mention any Orientalist of leading note in England who is not a member of this Congress. In addition to these, Prof. Dr. Brugsch will represent Egypt. France will be represented by upwards of thirty members, of whcm we may mention M. François Lenormant, Professor of Archæology at the French Institute; Prof. Jules Oppert, whose labours on the Cuneiform languages are well known; and Prof. Léon de Rosny, who was president of the Congress last year. Germany is also well represented, sending such men as Prof. Brockhaus of Leipzig, a leading expounder of the old school of Sanscrit learning, with whom we may unite the name of Prof. Stenzler of Breslau; Prof. Dillmann of Berlin, chiefly known for his Ethiopic researches and his valuable lexicon and catalogues of Ethiopic MSS. in the British Museum and the Bodleian Library; Herr Euting, Librarian of Strassburg, who has specially studied Phœenician inscriptions; Prof. Haug of Munich, whose particular branch of study is the Sanscrit, Zend, and Pehlvi languages; Prof. Krehl of Leipzig, an illustrious Arabic scholar; Prof. Lepsius of Berlin, an Egyptologist of universal repute; Prof. Nöldeke of Strassburg, who takes prominence for his knowledge of Arabic and Syriac, and has lately published works on the modern language of Syria ; Herr Pertsch, Librarian of Gotha ; Prof. Roth of Tübingen, whose Sanscrit Lexicon of the University of St. Petersburg is perhaps the best work of its kind; Prof. Spiegel, famed for deep studies in the Zend-Avesta and languages of Persia; Herr Trumpp of Miunich, privatdocent, and Iately appointed Professor of Arabic and Persian, who has published many works in the language of Afghan, Sindhi, and Punjabi ; Prof. Weber of Berlin, 
a Sanscrit authority of the new school; Prof. Weil and Prof. Windisch, both of Heidelberg, the former noted for Arabic learning, the other for Sanscrit and Celtic studies.

The programme of meetings is as follows :-

Sept. I4.--Inaugural Meeting. With Address. 8.30 P.M., at the Royal Institution, 2I, Albemarle Street. The meeting will commence with the election of the Council.

Sept, I 5.-Semitic Section. President, Sir Henry Rawlinson, K.C.B. Secretary, W. S. Vaux, Esq., F.R.S. Sitting, 2.30 P.M., at the rooms of the Royal Society of Literature, 4, St. Martin's Place, Charing Cross.

Sept. 16. - Turanian Section. President, Sir Walter Elliot, K.C.S.I. Secretary, Prof. Douglas. Sitting, 8.30 P.M., at King's College, Strand.

Sept. 17.-Aryan Section. President, Prof. Max Müller. Secretary, Prof. Eggeling. Sitting, 2.30 P.M., at the Royal Institution, 21, Albemarle Street.

Sept. 17.-Hamitic Section. President, Dr. Birch, LL.D. Secretary, W. R. Cooper, Esq. Sitting, 8.30 P.M., at the rooms of the Society of Biblical Archrology, 9, Conduit Street.

Sept. 18.-Archreological Section. President, M. Grant Duff, Esq., M.P. Secretary, E. Thomas, Esq., F.R.S. Sitting, Ir A.M., at the rooms of the Royal Asiatic Society, 22, Albemarle Street.

Sept. I9.-Ethnological Section. President, Prof. Owen, C.B. Secretary, R. Cull, Esq., F.S.A. Sitting, 2.30 P.M., at the rooms of the Royal Asiatic Society, 22, Albemarle Street. At the close of the sitting the members of the Congress will decide in what country the next Congress shall be held, and will nominate the president.

There will be receptions on the following occasions :--

Sept. 15.-IO A.M., at the British Museum.

Sept. 16.-II A.M. The Right Hon. Sir Bartle Frere will give a breakfast to the members of the Congress, at his residence, Wressil Lodge, Wimbledon.

Sept. 17.-1O A.M., at the India Office Library. I2 noon, at the Soane Museum.

Sept. I8. - Mr. Bosanquet will g:ve an afternoon garden party to the members of the Congress, at his residence, Claymoor House, Enfield.

Sept. 19.-10 A.M., at the South Kensington Museum.

During the meeting of the Congress a Bureau will be opened at the Royal Asiatic Society's Rooms, 22, Albemarle Street, W., where every information concerning the Congress may be obtained.

The Committee of the Scientific Club have kindly invited the members of the Congress to make use of their club house, 7 , Savile Row, W., during the session of the Congress. The foreign members of the Congress and their friends are invited by the Council of the Royal Botanic Society of London to visit the gardens of the Society, in Regent's Park, at any time during their stay in London. Such members will be admitted to the gardens by producing their cards of membership.

\section{ANDERS FONAS ANGSTRÖM}

A NDERS JONAS ANGSTRÖM, Professor of Physics $A$ in the University of Upsala, after a short illness of less than a fortnight, died, as we have already announced, on June 20 , from an attack of inflammation of the brain. The death of Prof. Angström, who has been cut down in the full vigour of his powers and in the midst of a noble and active scientific career, is a loss to the entire world of science.

Angström was born Aug. 13, I814, at the Lögdo Iron Works Settlement in Medelpad. He was the son of a pastor, who in the early childhood of Anders Jonas, removed to Ullänger, in Angermanland, and a few years afterwards to Sätna in the neighbourhood of Sandsvall, where he remained till his death in 1847 . With no other means than the extremely limited stipend of a Swedish country minister, supplemented by the proceeds of a small glebe, the elder Angström kept his three sons-the present Dr. Johan Angström and Prof. Anders Jonas and his young brother Carl Arendt at school, and even assisted them in their subsequent attendance at the University classes at Upsala. In these efforts the father was strenuously supported by his wife, without whose good management such efforts would have been impracticable; and to advanced age this admirable housewife continued to prosecute her daily task of spinning, without remitting her active supervision of her household.

Although circumstances compelled Angström to eke out the means necessary for his University course by his own exertions, he passed through all his requisite examinations with distinction and within the usual terms. After matriculating in the autumn of 1833 , he took the degree of Doctor of Philosophy in 1839 ; became a physical tutor in the same year, and assistant in practical astronomy in 1843 ; while in the years 1846 and 1847 he fulfilled the duties of the Chair of Astronomy at the University, during the temporary absence on the continent of the professor. Owing to want of interest he had, however, five years to wait before he obtained any other fixed employment. The Chair of Physics had fallen vacant in 1839, the same year in which Angström graduated; but then, and for some time afterwards, his abilities were rot fully recognised in the University, while with his natural modesty he abstained from presenting himself as a candidate, although he might then have enjoyed the same good fortune as his friend and fellowstudent, Malmsten, who, after having had four years in which to preprare himself, was able on the death of the Professor of Mathematics, in the year I843, to offer himself as a successful candidate for the vacant chair. At length, in 1858 , on the public recommendation of the Consistory, Angstrom was nominated to the Chair of Physics, the duties of which he had performed for two years in the character of a pro tempore professor. This chair he continued to hold for the remaining sixteen years of his life.

During his occupancy of the chair Angström secured for the physical museum of the University an admirable collection of instruments for the determination of different exact measurements in the various departments of physical science; and as far as the limited resources at his disposal permitted, he improved the physical laboratories, and strove to awaken amongst the students an interest in the study of the exact sciences. He also continued for a number of years, in the capacity of Secretary to the Royal Society at Upsala, to conduct its transactions with a zeal and devotion which secured for him the grateful recognition of foreigners as well as of his own countrymen.

Although Angström published memoirs on almost all branches of physical science, his name will be for ever associated with the history of spectral analysis, for which he obtained from the Royal Society of London in 1870 the Rumford gold medal, a distinction which no Swede had ever before enjoyed.

In order to show Angström's' place in scientific history in regard to this class of researches, it will be well in this place to briefly recapitulate the capital points.* * This recapitulation is based upon the historical statement in Lockyer's
"Solar Physics." 